\title{
ПОНЯТТЯ «ГРУПОВИЙ ПОЗОВ» ЯК ЕЛЕМЕНТ ПРОСТОЇ МНОЖИННОСТІ
}

У всіх зарубіжних країнах незалежно від діючого правового режиму існують аспекти щодо порушення прав, свобод і законних інтересів громадян. 3 огляду на планомірний i стрімкий розвиток міжнародної економіки зазначене явище стає масовим. Здебільшого за останні роки важливим є збільшення кількості порушень щодо значного кола осіб, зросло навантаження на судову систему держави, тому суди змушені розглядати велику кількість однотипних позовів.

В Україні актуальним є завдання забезпечення захисту прав великого кола осіб, і найважливішим аспектом цієї проблеми є необхідність ефективного правового захисту групи учасників судового провадження. За відсутності ефективного захисту таких учасників неможливо чітко дотримуватися принципу права на справедливий судовий розгляд справи.

Дослідженням понять «груповий позов» присвятили свої праці відомі вчені різних галузей правової науки. Вказану дефініцію досліджували Г.О. Аболонін, Д.Я. Малешин, А.В. Губська, це поняття розкривали Е.I. Чугунова, М.Д. Лукашова, Д.А. Туманов. Теоретичне дослідження інституту групового позову здійснювали М. Єлісеєв, А.Ю. Абаніна, С. Юдіна, М.А. Рожкова. Чітке формулювання «груповий позов» та основні аспекти його впровадження запропонував П. Ларссон.

Мета дослідження є розробка теоретичної та практичної концепції правового регулювання інституту групового позову, доцільності такого судового провадження в теорії та на практиці, достеменне створення пропозицій щодо удосконалення законодавства у цій сфері.

Універсальний засіб захисту порушених прав і законних інтересів - складне явище, сутність якого складається з процесуально-правових аспектів. Але перш ніж розглянути кожну сторону позову, слід визначити, чим є поняття «позову» або в нашому випадку - «колективного позову» чи «групового», як його трактують вчені-теоретики.

M. Єлісеєв ототожнює груповий, колективний i позов на захист прав i свобод невизначеного кола осіб, спираючись на практику зарубіжних країн, і констатує, що у Франції реалізація захисту прав великого кола осіб може проводитися ними ж самостійно, а також за допомогою представництва у формі об'єднань [1, с. 489].

Д.Я. Малешин також говорить про їхню схожість, адже поняття «груповий позов» $€$ теоретичною конструкцією і служить для позначення порядку захисту прав значного кола осіб, i концептуальною виявляється термінологія, яка у різних процесуальних системах використовується по-різному [2, с. 117]. Це підтверджує, наприклад, дослідження Г.О. Аболоніна, котрий вміщує всі ці поняття у термін «масові позови» [3, с. 5].

Д.А. Туманов констатує, що вказаний термін дійсно слід використовувати суто для стислості, адже інститут множинності не завжди має на увазі наявність якогось єдиного позову 3 одним предметом і підставою [4]. 


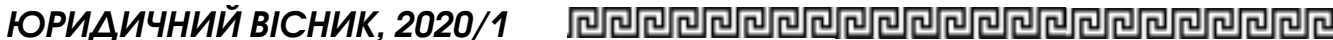

Дослідження аспектів масового позову в адміністративному процесі $є$ досить актуальним, адже у визначенні цього концепту у теорії адміністративного процесуального права немає одностайності. Головною ознакою таких позовів є, відповідно, захист прав та інтересів не індивідуальної особи, а цілої групи осіб. Оскільки в самих поняттях «колективний», «груповий», «масовий» позови містяться елементи множинності учасників процесу, то слід констатувати віднесення вказаних позовів до процесуальної співучасті.

Процесуальна співучасть - це участь в одному і тому самому процесі кількох позивачів і / або відповідачів, право вимоги або обов'язки яких не виключають одне одного [5, с. 35].

Слід зауважити, що деякі вчені вважають, ніби такі позови не належать до реалізації інститутом процесуальної співучасті. Наприклад, Ю.Ю. Трач звертає увагу на те, що груповий позов i співучасть мають тільки зовнішню схожість і є різними інститутами процесуального права, адже співучасть має на меті пришвидшення процесу тільки шляхом об'єднання декількох вимог і не дає можливостей обмежитися поясненнями окремих співучасників, які не встановлюють особливих вимог слухання справи в разі відсутності кого-небудь зі співучасників, і не визнає винятки в наслідках неявки співучасника на судове засідання, а це $€$ достеменною відмінністю від групового позову, спрямованого на те, щоб позивачі активно реалізували своє право на судовий захист, зорганізувалися таким чином, щоб якнайбільше спростити процедуру судового розгляду при дотриманні прав і без шкоди для винесення законного й обгрунтованого рішення [6].

Також лишається питання про співвідношення групового позову і процесуальної співучасті.

А.Ю. Абаніна говорить, що між цими інститутами відсутнє чітке розмежування в науці та що непродуманість законодавчого регулювання позо- вів на захист певного кола осіб має своїм наслідком незатребуваність цього нового інституту в судовій практиці [7].

Здається, що відмінності групових позовів і процесуальної співучасті зумовлені такими обставинами:

1. розгляд судом групового позову не вимагає особистої участі у провадженні по відповідній справі, а за співучасті співучасники, звісно, наділені правом ухилитися від особистої участі у процесі, доручивши ведення справи одному з них, однак кожен зі співучасників є стороною у процесі;

2. загальною для обох інститутів ознакою є ї масовість, тобто кількість учасників і їхні вимоги такі, що індивідуальна участь кожного з них у судовому процесі є практично невигідною;

3. при розгляді справ з ознаками групи учасників завжди $€$ обов'язкова співучасть, тому судове рішення виноситься для всіх його учасників, а винятком можуть бути тільки ті, хто оголосив про свій вихід із групи;

4. процесуальній співучасті притаманна реалізація власних інтересів кожного зі співучасників від свого імені, а за справи щодо групи (колективу), права і законні інтереси всієї групи захищені від імені позивача.

Слід констатувати, що такий підхід до вирішення питання щодо співвідношення вказаних інститутів не $€$ чітко обгрунтованим та аргументованим, адже при дослідженні ї сутності головним вважається те, що кожен із них $€$ чітким і самостійним способом захисту прав великого кола осіб у процесі зважаючи на характер інтересу.

Влучно висловився В. Ярков, котрий зазначає, що груповий позов виявився тим процесуальним засобом, який дозволяє за допомогою процесуального інструментарію ефективно захищати інтереси великих груп громадян і організацій, що опинилися в однаковій юридико-фактичній ситуації, якщо їх права й інтереси порушені загальним відповідачем [8].

Отже, зазначимо основні аспекти такого позову для більш чіткого та грунтовного його розуміння: 
1. груповий (колективний) позов це звернення певного або невизначеного кола осіб, виражене у вимозі до суду щодо захисту порушених прав, свобод та інтересів;

2. суб'єктом групового позову визнається коло осіб, яке є визначеним або невизначеним;

3. колективний (груповий) позов має за основу однотипні матеріальні вимоги суб'єктів правових відносин;

4. рішення, що виноситься судом у справах за участі великого кола осіб, є загальнообов'язковим для абсолютно всіх учасників у процесі.

Позов, який має ознаки масовості, $€$ концептуальним явищем, що складається 3 матеріально-правової та процесуально-правової сторін. Те чи інше звернення до суду щодо відновлення порушених законних інтересів і прав супроводжується подачею позову і містить дві вимоги: по-перше, вимогу позивача до суду, по-друге, вимогу позивача до відповідача.

Так, наприклад, 17 липня 2018 р. Верховний Суд у складі колегії суддів Касаційного адміністративного суду відмовив у задоволенні позову групи осіб до Верховної Ради України про визнання протиправною бездіяльності [9].

Правовий інститут групових позовів $€$ відносно новим для внутрішнього процесуального законодавства. Водночас у законодавстві ряду зарубіжних країн він виконує значну роль, що вимагає окремого розгляду відповідних питань.

С. Юдіна зазначає, що у Європі правовий інститут групових позовів заснований на положеннях Білої книги, адже інститут колективних позовів має на меті обмеження прав зацікавлених осіб, контроль за діями особи, котра звернулася по захист прав, прийняття законів про групові позови має обговорюватися професійним співтовариством [10].

Вибір тієі чи іншої моделі групового позову державами здійснювався виходячи зі сформованих традицій і передумов. Наприклад, першовідкривачем застосування групових позовів були
Англія та США, де колективні групові позови стали неймовірно популярними.

Як зазначає Г.О. Аболонін, у судовій системі США за груповими позовами застосовуються специфічні правила процесу, тобто кожна зі сторін повинна сама нести свої судові витрати, пов'язані із судовою справою, а стороні, на бік якої ухвалено рішення, всі понесені нею судові витрати з іншого боку не присуджуються [11].

Однією з важливих характеристик групових позовів для удосконалення їх реалізації в адміністративному процесі України $€$ функціонування інституту групового позову за методами «opt-in» та «opt-out», притаманними англійській та американській моделі регулювання:

1. позови «opt-in» - це метод, коли учасниками групи стають тільки ті особи, які прямо заявлять про свою волю приєднатися до групового позову.

Наприклад, Rachael Mulheron зазначає, що цей метод допускає, по-перше, свободу вибору у пред'явленні позову; по-друге, уникнення значних витрат і труднощів; по-третє, всі потенційні особи, які $€$ учасниками групового позову, пов'язані однотипними правовідносинами й інтересом внаслідок розгляду справи; по-четверте, має недоліки у вигляді неповного забезпечення доступу до правосуддя належним для нього чином [12].

2. позови «opt-out»- це метод, коли учасниками групи стають всі особи, які не надали своєї відмови від приєднання до групового позову.

Принцип такої моделі заснований на тому, що один або декілька позивачів можуть подати груповий позов на захист своїх порушених прав та інтересів, а також усіх тих, хто хоча б за формальними ознаками може потрапити в цю групу. Інші потерпілі можуть навіть і не знати про майбутній судовий процес або ж дізнатися про нього значно пізніше. Суть такої моделі в тому, що груповий позов передбачає за замовчуванням участь всіх, хто тим чи іншим чином не заявив про свою відмову бути учасником групового позову. 


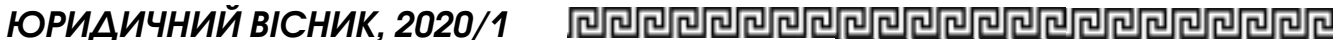

Якщо повернутися до особливостей подачі групового позову, то такий позов подається ініціатором, тобто тим, до кого надалі приєднуються всі інші зацікавлені особи у процесі. Виходячи 3 такого трактування, ініціатор позову повинен нести витрати по сплаті державного мита одноосібно.

Проте така позиція не зовсім правильна, адже все навантаження щодо витрат лягає на одну особу. Подекуди це може бути обтяжливо, а з іншого боку, при подачі групового позову «перший» матиме можливість всебічно і повно дати оцінку своїм фінансовим можливостям і перспективі на отримання позитивного результату за заявленими вимогами.

Однак слід зауважити, що після винесення рішення за груповим позовом і в разі його задоволення воно набирає законної сили та підлягає обов'язковому виконанню. У зв'язку з цим виникають два питання: по-перше, як буде виконуватися судове рішення, а, по-друге, яким чином будуть розподілені судові витрати. А тому, оскільки рішення має бути виконане стосовно кожного члена групи, необхідно визначити, що суд повинен зобов'язати ініціатора позову або через засоби масової інформації, або іншим чином проінформувати всіх учасників групи, адже він виступає на захист інтересів всієї групи осіб, а інші, будучи безправними під час судового процесу, можуть тільки знайомитися 3 матеріалами справи, робити 3 них виписки або знімати копії, вони залишаються безправними і під час виконання рішення суду.

Перевагою застосування групового позову $є$ утворення групи осіб до початку судового розгляду 3 максимальною кількістю осіб, зниження навантаження на судові органи шляхом позбавлення їх від однотипних позовів.

Слід зазначити і недоліки застосування групових позовів, які здебільшого зумовлені новизною цього інституту: по-перше, звернення до суду можливе тільки у випадку, прямо передбаченому законом; по-друге, за наявності однотипних правових відно- син; по-третє, в разі неприєднання до групового позову втрачається можливість подати індивідуальний позов.

Групові позови нерідко називають колективними [13]. Не можна стверджувати, що вказані терміни правильно відображають правову природу вказаного конструктиву. У Великому тлумачному словнику сучасної українької мови вказується, що група сукупність осіб, об'єднаних спільною метою, ідеєю та працею, а колективом визнається сукупність людей, об'єднаних спільною діяльністю, спільними інтересами [14, с. 440].

Тому слід зробити висновок, що обидва вказані терміни не дуже відрізняються один від одного, але мають право на самостійний генезис.

Якщо поглянути на тлумачення вказаних двох понять, то груповий позов не можна ототожнювати 3 колективним. Це твердження грунтується на тому, що позивачі при реалізації цих двох інститутів мають різний зв'язок, який зумовлюється однотипністю інтересів, що потребують захисту й об'єднані загальними підставами для позову, а пояснюється все тим, що при груповому позові особи мають зацікавленість тільки в індивідуальному плані, а за іншого - проявляється зацікавленість на користь усієї групи осіб.

Тому найбільш правильним підходом, мабуть, є те, що групова вимога $€$ письмовою апеляцією до суду, яка виконана від імені великої групи осіб та в якій міститься вимога до відповідача на підставі загального юридичного факту або загальна вимога про відновлення порушеного права, висунутого в інтересах всіх учасників групи осіб, розгляд яких здійснюється судом.

Тому на підставі проведеного аналізу інституту групового позову та його співвідношення 3 іншими галузями, вбачаємо необхідним структурування та повну регламентацію цього інституту на законодавчому рівні, роз'яснення випадків подання таких позовів і перелік нормативних актів, що їх передбачають. 
У наданій до розгляду статmі автор досліджуе питання, пов'язані з поняттям і сутністю інституту групового позову. Стаття присвячена актуальній проблематиці, що характеризується міждисииплінарністю.

Мета роботи - проаналізувати сучасну ситуацію щзодо реалізациї інституту групового позову на міжнародній арені та в Україні, розглянути ключові у юридичній науці позиції, визначити на глибинному рівні особливості розуміння досліджуваного концепту. Проведено аналіз важливих ознак $і$ сформульовано поняття позову, проведено відмежування від сумінних юридичних явищ.

На основі відповідної судової практики та наукової теоретичної бази було проаналізовано та систематизовано основні підходи до визначення цзього поняття. Сформульовано важливий висновок про те, що у контексті правозастосування така ідея наповнюеться якісно новим змістом.

Автор досліджуе досвід проведення інституиійних класових дій i можливість його використання $у$ процесуальному законодавстві України, визначае особливості провадження.

У статті розглядаються групові позови в системі процесуальних форм захисту. Сформульовані особливості иієї форми захисту в контексті проиесуальної множинності. У роботі досліджено низку наукових підходів до визначення поняття «проиесуальна участь», його правову природу. Увага приділяється питанням розмежування сумінних процесуальних інститутів - процесуальної участі та групового позову.

Теоретична значимість дослідження полягає в подальшому вивченні застосування групового позову в державі, виявленні проблемних моментів при їх реалізаиії. Практична значимість полягає в аналізі застосування на практиці судами норм $і$ усунення прогалин у законодавстві. Загалом значимість дослідження зумовлена комплексний характер аналізованої проблеми, поєднанням у ній теоретичних $i$ практичних аспектів.

Здійснена детальна характеристика основних складників права на судовий захист за множинності учасників у процесі, а також обтрунтовано те, що ие право можна реалізувати тільки за наявності ефективного механізму судового захисту.

Ключові слова: множинність, процесуальне законодавство, груповий позов, колективний позов, процесуальна співучасть.

\section{Rafalska O. Concept "group lawsuit" as element of simple multiplicity}

In the article given to consideration an author investigates the questions related to the concept and essence of institute of group lawsuit. The article is sanctified to the actual range of problems, that is characterized by analyze in different disciplines.

The author has reached the aim to analyze the modern situation of realization of institute of group lawsuit in the international arena and in the process of Ukraine, to consider key in legal science positions, define the features of understanding of the investigated concept at deep level. The analysis of important signs is conducted and the concept of lawsuit is set forth, dissociation is conducted from the contiguous legal phenomena.

On the basis of corresponding judicial practice and scientific theoretical base it was analyzed and systematized basic going near determination of this concept. An important conclusion is set forth that in the context of enforcement, such idea is filled with qualitatively new maintenance that answers as to national so international association.

An author investigates experience of realization of institutional class actions and possibility of his use in the judicial 


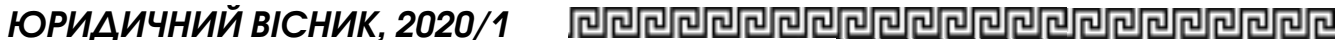

legislation of Ukraine, determines the features of realization.

In the article group lawsuits are examined in the system of judicial forms of defense. The set forth features of this form of defense are in the context of judicial multiplicity. In this work the row of the scientific going is investigational near determination of concept "judicial participation", investigational him legal nature. Paid attention to the questions of differentiation of contiguous judicial institutes - judicial participation and group lawsuit.

Theoretical meaningfulness of research consists in the further study of application of group lawsuit in the state, exposure of problem moments during their realization. Practical meaningfulness consists in the analysis of application in practice the courts of norms and removal of blanks in a legislation. On the whole, research meaningfulness carries complex character, combination of theoretical and practical aspects.

Realized detailed description of basic component elements of law on judicial defense at multiplicity of participants in a process, and also reasonably that this right can be realized only at presence of effective mechanism of judicial defense.

Key words: multiplicity, procedural law, group lawsuit, collective lawsuit, procedural participation.

\section{Література}

1. Елисеев Н.Г. Гражданское процессуальное право зарубежных стран : учебник. Москва : Проспект, 2004. 624 с.

2. Малешин Д.Я. Гражданская процес- суальная система России. Москва : Стаmym, 2011.

3. Аболонин, Г.О. Массовые иски. Москва : Волтерс Клувер, 2011.

4. Туманов Д.А. О групповых исках в Концепциии единого Гражданского процессуального кодекса РФ. Вестник гражданского процесса. 2015. № 4. С. 63.

5. Абова T.E. Соучастие в советском гражданском процессе. Избранные труды. Гражданский и административный процесс. Гражданское и хозяйственное право. Москва : Cmamym, 2007. 1134 c.

6. Трач Ю.Ю. Окремі аспекти відмінності групового позову та процесуальної співyчacmi. URL: http: / / wrw.lex-line.com.ua / ? language $=$ ru\&go $=$ full_article\&id $=392$.

7. Абанина А.Ю. Проиессуальное соучастие и групповой иск по АПК РФ: сходство и отличие. Арбитражный и гражданский процесс. 2011. № 1. С. 19.

8. Ярков В.В. Групповой иск в проекте единого ГПК России. Вестник экономиче ского правосудия Российской Федерациии. 2015. № 8. C. 101.

9. Рішення Верховного Суду в справі № 800/201/17. URL: http:// reyestr.court. gov.ua/Review / 75382724 .

10. Юдина С. Взыскание убытков и коллективные иски в антимонопольном праве. Конкуренция и право. 2013. № 5. С. 20.

11. Аболонин, Г.О. Правовой механизм группового иска в США. Вестник гражданского процесса. 2015. № 3. С. 169.

12. Rachael Mulheron. Some difficulties with group litigation orders - and why a class action is superior. Civil Justice Quarterly. 2005. № 24. C. 50-51.

13. Рожкова М.А. И вновь о групповых и косвенных исках. Вестник Высшего Арбитражного Суда Российской Федерации. 2007. № 5. C. 19-36.

14. Великий тлумачний словник сучасної української мови / уклад. і голов. ред. B.T. Бусел. Київ ; Iрпінь : ВТФ «Перун», 2003. $1440 \mathrm{c}$. 